\title{
IDENTIFYING THE EFFECT OF TIDES ON GROUNDWATER LEVEL FLUCTUATIONS ON GILI KETAPANG ISLAND, INDONESIA
}

\author{
Agung Dwi PURNOMO ${ }^{1}$, Muh Aris MARFAI ${ }^{\star}$, Semeidi HUSRIN ${ }^{2}$ \\ ${ }^{1}$ Faculty of Geography, Universitas Gadjah Mada, Yogyakarta, Indonesia \\ ${ }^{2}$ Marine Research Center, Research Agency and Human Resources Development, \\ Ministry of Marine Affairs and Fisheries (KKP), Jakarta, Indonesia
}

Received 22 January 2020; accepted 21 December 2020

\begin{abstract}
Highlights
The sea level in the study area showed the occurrence of elevating caused by standing waves. Despite the standing wave phenomenon, the sea level around the island has a similar.

Groundwater conditions showed that the largest fluctuations level occurred during the new moon phase.

The effect of tides on the groundwater level characterized by decreasing in amplitudes and time lags as increasing the distance from the coast.
\end{abstract}

\begin{abstract}
This research aims to identify the effect of tides on groundwater level fluctuation in Gili Ketapang Island by using a combination of field monitoring and hydrodynamic modeling. Groundwater data were collected from 5 July to 17 August 2018 from two wells monitoring, while the hydrodynamic model was adopted to identify sea-level conditions. The result explains the sea level around the island is similar among extremely strong correlations between the points. The hydrodynamic model proves a standing wave due to tidal amplification in Madura Strait waters. The effect of tides on the groundwater level characterized by decreasing in amplitudes and time lags as increasing the distance from the coast.
\end{abstract}

Keywords: tides, groundwater level fluctuations, Gili Ketapang Island, hydrodynamic model.

\section{Introduction}

Indonesia is the largest archipelago country in the world, with a total of 17,504 large and small islands. Falkland et al. (1991), defined a small Island as a land with an area less than $2,000 \mathrm{~km}^{2}$ or widths below $10 \mathrm{~km}$, while a very small island has an area of fewer than $100 \mathrm{~km}^{2}$ or widths below $3 \mathrm{~km}$. Small islands consist of geological, hydrological, demographic, and socio-economic unique characteristics. Falkland (1993) reported that the factors that influence the existence of water resources on small islands included (1) physiography (2) climate and hydrology (3) geology and hydrogeology (4) land and vegetation (5) humans and for flat islands (5) sea-level fluctuations, such as tides. Most of the oceanic island is relatively permeable consisting of sand, coral, or limestone and having contact by seawater on all sides (Todd, 1980); moreover have phreatic groundwater with saline groundwater underlying the freshwater (Fetter, 1972).
Freshwater resources of small islands are limited because it is affected by tides in the daily and rain in the annual (Narulita et al., 2005). According to Purnama (2010), tides are one of the factors that affected groundwater level fluctuations, while (Levanon et al., 2016), showed there were interactions between these two attributes in the form of groundwater level position change. Dong et al. (2015) stated a seasonal and diurnal water level fluctuation in coastal aquifers is typically caused by oceanic tidal and barometric variations. On low coral islands, the groundwater lens is a vital source of freshwater for the terrestrial ecosystem and domestic consumption (White et al., 2007).

Several researchers have conducted studies related to tidal - groundwater interactions with various methods. The summary obtains as follows:

- analytical solutions (Nielsen, 1990; Jeng et al., 2002; Dong et al., 2015; Huang et al., 2015 etc);

- numerical modeling (Ataie-Ashtiani et al., 2001; Pauw et al., 2014; Levanon et al., 2016 etc);

${ }^{*}$ Corresponding author. E-mail: arismarfai@ugm.ac.id 
- field monitoring (Kim et al., 2005, 2006; Abarca et al., 2013; Narulita et al., 2005; Opatz \& Dinicola, 2018; Singaraja et al., 2018 etc).

Many studies take locations such as islands and coastal areas directly exposed to sea waters, while a few highlight the bay waters. Whereas in the bay waters area tidal amplification often occurs as explained by Dean and Dalrymple (1991), Hadi and Radjawane (2010), Van Rijn (2011), and Holleman and Stacey (2014), where one of the effects of amplification is related to coastal area inundation such as Holleman and Stacey (2014), Hill (2016), and Kusmanto et al. (2016). This term has an impact on the condition of coastal groundwater especially on small islands, where the combination of tides, the phenomenon in the bay waters, and groundwater has not been much considered. Therefore, this research attempts to implement this. Previous studies regarding tidal-groundwater relations are shown in Table 1.

Table 1. Literature review related to the tidal-groundwater topics

\begin{tabular}{|c|c|c|c|}
\hline Authors & Area & Methods & Aims \\
\hline $\begin{array}{l}\text { Abdullah et al. } \\
(1997)\end{array}$ & $\begin{array}{l}\text { Sipadan Island, } \\
\text { Malaysia }\end{array}$ & ield monitoring & $\begin{array}{l}\text { Determine the effect of tidal change on the groundwater quality } \\
\text { of such an island using temperature, dissolved oxygen content, } \\
\text { conductivity, salinity, and } \mathrm{pH}\end{array}$ \\
\hline $\begin{array}{l}\text { Urish and } \\
\text { McKenna (2004) }\end{array}$ & $\begin{array}{l}\text { Nauset Marsh, } \\
\text { Massachusetts, } \\
\text { USA }\end{array}$ & Field monitoring & $\begin{array}{l}\text { Provides new insights into the coastal groundwater discharge } \\
\text { phenomenon by describing the result of field study on tidally } \\
\text { influenced sandy beaches }\end{array}$ \\
\hline Kim et al. (2005) & $\begin{array}{l}\text { Kimje Coastal } \\
\text { Area, Korea }\end{array}$ & Field monitoring & $\begin{array}{l}\text { Time series analysis for identification of tidal effect on groundwater } \\
\text { quality }\end{array}$ \\
\hline Jeng et al. (2005) & $\begin{array}{l}\text { Ardeer, } \\
\text { Scotland }\end{array}$ & $\begin{array}{l}\text { Field monitc } \\
\text { numerical m }\end{array}$ & $\begin{array}{l}\text { Combine the tidal influence on groundwater dynamics, saltwater } \\
\text { intrusion, and chemical transport in a coastal aquifer model to } \\
\text { elucidate their interactions }\end{array}$ \\
\hline Xun et al. (2006) & Beihai, China & Field monitoring & $\begin{array}{l}\text { Investigate tidal effect on groundwater level in Beihai coastal } \\
\text { aquifer }\end{array}$ \\
\hline $\begin{array}{l}\text { Vandenbohede and } \\
\text { Lebbe (2007) }\end{array}$ & $\begin{array}{l}\text { Belgian coastal } \\
\text { plain, Belgia }\end{array}$ & Numerical modeling & $\begin{array}{l}\text { Influences of tides on the groundwater flow in a phreatic aquifer } \\
\text { situated under the dunes and a gently sloping shore }\end{array}$ \\
\hline Mao et al. (2006) & $\begin{array}{l}\text { Ardeer, } \\
\text { Scotland }\end{array}$ & numerical modeling & $\begin{array}{l}\text { Identify in particularly the effect of tidal fluctuations at a midly } \\
\text { sloping beach }\end{array}$ \\
\hline $\begin{array}{l}\text { Robinson et al. } \\
(2007)\end{array}$ & $\begin{array}{l}\text { experimental } \\
\text { data }\end{array}$ & Numerical modeling & $\begin{array}{l}\text { A detailed parametric study investigating the rate of water exchange } \\
\text { across the aquifer-ocean interface driven by tidal forcing }\end{array}$ \\
\hline $\begin{array}{l}\text { Wu and Zhuang } \\
(2010)\end{array}$ & $\begin{array}{l}\text { experimental } \\
\text { data }\end{array}$ & Numerical modeling & $\begin{array}{l}\text { Identify characteristics of groundwater table fluctuation and } \\
\text { influencing factors }\end{array}$ \\
\hline $\begin{array}{l}\text { Banerjee et al. } \\
(2012)\end{array}$ & $\begin{array}{l}\text { Kalpeni Island, } \\
\text { India }\end{array}$ & Field sam & $\begin{array}{l}\text { Reporting the groundwater quality and salinization on shallow } \\
\text { groundwater regime in a small coral island }\end{array}$ \\
\hline Liu et al. (2012) & $\begin{array}{l}\text { experimental } \\
\text { data }\end{array}$ & Numerical modeling & $\begin{array}{l}\text { Investigate the influences of different beach slopes on the tide } \\
\text { induced water table fluctuation and the groundwater dynamics in } \\
\text { the transition zone based on designed numerical scenarios }\end{array}$ \\
\hline Abarca et al. (2013) & $\begin{array}{l}\text { Waquoit Bay, } \\
\text { Massachusetts, } \\
\text { USA }\end{array}$ & $\begin{array}{l}\text { Field monitoring, } \\
\text { tracer injection \& } \\
\text { numerical modeling }\end{array}$ & $\begin{array}{l}\text { Present the evidence of the complex interaction among the } \\
\text { intertidal saline cell, the deep saltwater wedge, and fresh water } \\
\text { discharge }\end{array}$ \\
\hline $\begin{array}{l}\text { Heiss and Michael } \\
(2014)\end{array}$ & \begin{tabular}{l|} 
Cape \\
Henlopen, \\
Delaware, USA
\end{tabular} & $\begin{array}{l}\text { Field monitoring \& } \\
\text { numerical modeling }\end{array}$ & $\begin{array}{l}\text { Identify the physical forcing conditions (i.e. tidal amplitude } \\
\text { variability and fluctuation in the inland water table) and time scales } \\
\text { that are the most important that controlling the structure and area } \\
\text { extent of the intertidal salinity distribution }\end{array}$ \\
\hline Dong et al. (2015) & $\begin{array}{l}\text { Kyushu Island, } \\
\text { Japan }\end{array}$ & Field monitoring & $\begin{array}{l}\text { Analyses the tidal and barometric effects on water level fluctuation } \\
\text { in a coastal aquifer near Ariake Sea }\end{array}$ \\
\hline Hsieh et al. (2015) & $\begin{array}{l}\text { experimental } \\
\text { data }\end{array}$ & Analytical solutions & $\begin{array}{l}\text { Linearizing the 1-D non-linear Boussineqs equation to characterize } \\
\text { the variation of groundwater level induced by tidal and rainfall in } \\
\text { coastal unconfined aquifer }\end{array}$ \\
\hline Huang et al. (2015) & $\begin{array}{l}\text { experimental } \\
\text { data }\end{array}$ & Analytical solutions & $\begin{array}{l}\text { Present the analytical model considering three tidal boundary } \\
\text { effects for U-shaped aquifers }\end{array}$ \\
\hline $\begin{array}{l}\text { Levanon et al. } \\
\text { (2017) }\end{array}$ & \begin{tabular}{l|} 
Nitzanim \\
Nature Reserve, \\
Israel
\end{tabular} & $\begin{array}{l}\text { Field monitoring \& } \\
\text { numerical modeling }\end{array}$ & $\begin{array}{l}\text { Validate the mechanism for tidal induced groundwater fluctuations } \\
\text { using time series analysis of field data and numerical simulations }\end{array}$ \\
\hline Zhang et al. (2017) & $\begin{array}{l}\text { Rorotonga, } \\
\text { Cook Islands }\end{array}$ & $\begin{array}{l}\text { Field monitoring \& } \\
\text { numerical modeling }\end{array}$ & $\begin{array}{l}\text { Investigate slope break effect on beach groundwater flow at a field } \\
\text { site }\end{array}$ \\
\hline $\begin{array}{l}\text { Jasonsmith et al. } \\
\text { (2017) }\end{array}$ & $\begin{array}{l}\text { Wybong Creek, } \\
\text { Australia }\end{array}$ & Field monitoring & $\begin{array}{l}\text { Investigate the influence of earth-tide in area study and identify } \\
\text { processes contributing to salinity in tributary of the river }\end{array}$ \\
\hline
\end{tabular}


End of Table 1

\begin{tabular}{|l|l|l|l|}
\hline \multicolumn{1}{|c|}{ Authors } & \multicolumn{1}{|c|}{ Area } & \multicolumn{1}{c|}{ Methods } & \multicolumn{1}{c|}{ Aims } \\
\hline $\begin{array}{l}\text { Singaraja et al. } \\
(2018)\end{array}$ & $\begin{array}{l}\text { Cuddalore } \\
\text { coastal region, } \\
\text { India }\end{array}$ & Field monitoring & $\begin{array}{l}\text { The relation between water table, dissolved oxygen, and electric } \\
\text { conductivity in the coastal aquifers and tidal influences in selected } \\
\text { three locations }\end{array}$ \\
\hline $\begin{array}{l}\text { Trglavcnik et al. } \\
(2018)\end{array}$ & $\begin{array}{l}\text { Sabe Island, } \\
\text { Canada }\end{array}$ & $\begin{array}{l}\text { Field monitoring \& } \\
\text { numerical modeling }\end{array}$ & $\begin{array}{l}\text { Practical use of a combined approache of analyzing signal } \\
\text { propagationof both tidal and storm pulse can provide insight into } \\
\text { structure of a heterogeneous coastal aquifer system }\end{array}$ \\
\hline $\begin{array}{l}\text { Opatz and Dinicola } \\
(2018)\end{array}$ & $\begin{array}{l}\text { Naval Base } \\
\text { Kitsap, } \\
\text { Keyport, } \\
\text { Washington }\end{array}$ & Field monitoring & $\begin{array}{l}\text { Determine the optimal time during the semi-diurnal and the } \\
\text { neap-spring tidal cycles to sample groundwater for fresh water } \\
\text { contaminant in monitoring wells }\end{array}$ \\
\hline
\end{tabular}

Some researchers identified interactions of tides and groundwater with several methods. The analytical solutions was carried out by Nielsen (1990); Jeng et al. (2002); Dong et al. (2015); and Huang et al. (2015). The numerical modeling was carried out by Ataie-Ashtiani et al. (2001); Pauw et al. (2014); dan Levanon et al. (2016). The field measurement was carried out by Kim et al. (2005, 2006); Abarca et al. (2013); Narulita et al. (2005); and Singaraja et al. (2018). Research on the interaction between tides and groundwater in coastal areas was mostly carried out by hydrogeochemical and geoelectric approaches. However, an understanding of groundwater fluctuations due to tides was rarely studied, especially on small island regions.

Gili Ketapang Island is located in the north of Probolinggo Regency and included in the Madura Strait waters. This very small island has an area of $0.68 \mathrm{~km}^{2}$ and a population density of 12,356 people $/ \mathrm{km}^{2}$ (Husrin, 2018). It has limited water resources, due to its large population. In addition, it is geographically surrounded by the waters of the Madura Strait, causing oceanographic influences, on the tides towards groundwater. The hydrogeological characteristics of Gili Ketapang Island are alluvium deposits and limestone. This study aims to identify the effect of tides on groundwater level fluctuations on Gili Ketapang Island. Research location is shown in Figure 1.

This study aims to identify the effect of tides on groundwater level fluctuations on a small island. This study applies hydrodynamic models which ordinarily used in hydrodynamic modeling of marine waters, such as Bayhaqi et al. (2018), Prihantono et al. (2018), and Wisha et al. (2018). The hydrodynamic model is implemented to recognize the bay waters phenomena in the research area. Several studies on hydrodynamic in the bay area have been provided such as Sutherland et al. (2005), Webb (2014), Cui et al. (2019), though no one has yet sought to associate the model with groundwater. The combination of hydrodynamic modeling and groundwater monitoring is expected to gain the explanations of the effect of tides induces groundwater.

\section{Methodology}

\subsection{Study area}

Gili Ketapang Island is an isolated coral island, located in the north of the Probolinggo Regency and included in the Madura Strait waters area. Gili Ketapang Island has an area of $0.68 \mathrm{~km}^{2}$ (classified as a very small island) with a population density of 12,356 people $/ \mathrm{km}^{2}$ (Husrin, 2018). The percentage of built areas on the island is approximately $90.28 \%$ or 65 hectares, while the non-built area was $9.72 \%$ or 7 hectares. The built area on the island is dominated by residential buildings with closely distances between houses. This dense-populated small island can produce pressure on the groundwater due to the impact of excessive groundwater abstraction.

Based on the Geological Map of Probolinggo at scale 1: 100,000, Gili Ketapang Island is composed of: (1) surface deposits (Qa), i.e. clay, mud, sand, pebble, cobble, boulder, and plant residues; and (2) coral limestone, i.e. coral limestone and sandy limestone. The eastern part of the island comprises a layer of the aquifer, in the northern part, there is a layer with a depth between $0-18 \mathrm{~m}$ below the surface and is increasingly thinning towards the south. In the middle part of the island with the north-south orientation, there is a relatively deep layer with a depth between $8-100 \mathrm{~m}$ below surface. Toward the east, the aquifer thickness is thinner because the eastern part of the island is dominated by compact limestone.

Gili Ketapang Island is controlled by the condition of oceanic drivers, like currents, waves, and tides. According to Hidayati et al. (2016), the dominant direction of the waves is northwest to southeast with a height of up to $0.33-0.58 \mathrm{~m}$. Formzahl value in the Madura Strait waters provides a value of 0.723 ; this indicates that the Madura Strait waters are classified as a tidal type of mixed tide prevailing semidiurnal. Kusmanto et al. (2016) stated that the tidal range in the Madura Strait waters is relatively high compared to the Java Sea. The location of this research is shown in Figure 1.

\subsection{Field monitoring}

The data used were tidal and groundwater fluctuations. Tidal data obtained were measured by the Marine Research Center and predicted by the TMD and Tidal Prediction Height from MIKE21. Field data were measured from 1 July 2018 at 12:20 PM till July 5, 2018, at 11:20 AM with measurement intervals of 10 minutes. This result was used to validate the MIKE21 simulation and TPXO 6.2 tidal prediction data carried out by the Tidal Model Driver (TMD) program. 


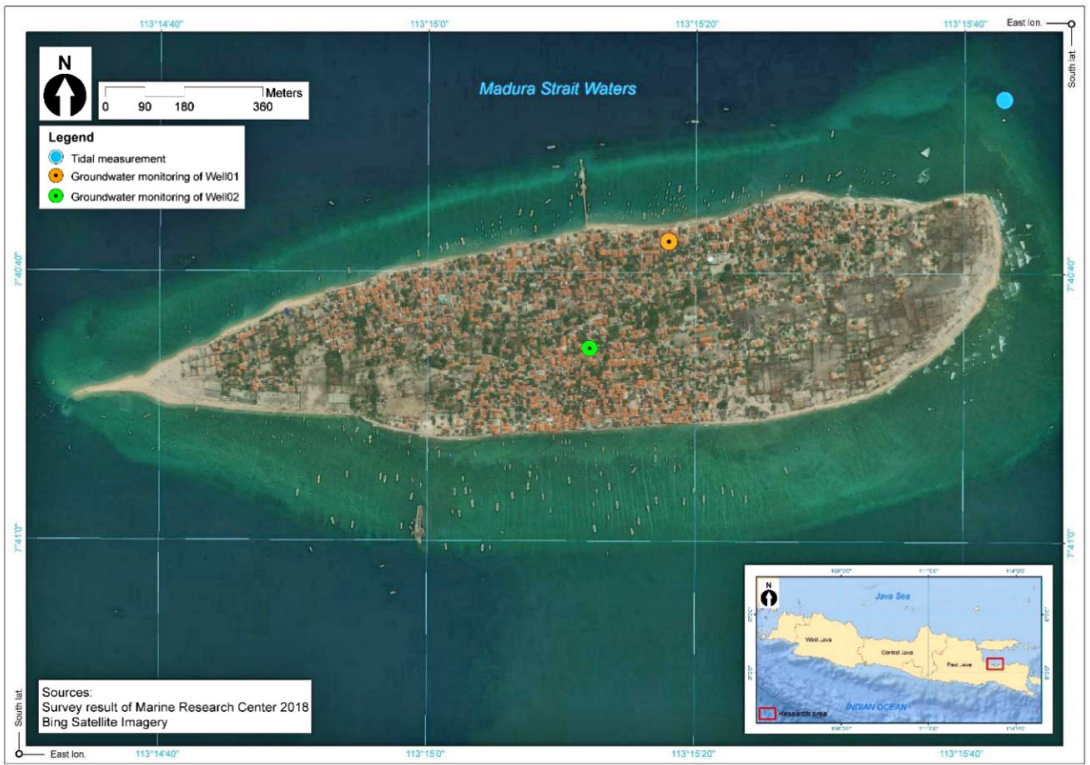

Figure 1. Map of research location in the Madura Strait waters includes showing locations of both tidal and wells monitoring. Tidal monitoring labeled with blue dot whereas the wells labeled by an orange and green dot

Field monitoring consists of both tidal and groundwater level monitoring. Tidal is measured on 1 July 2018 at 12.20 West Indonesia Time (WIB) until 5 July 2018 at 11.20 WIB with a 10-minutes interval, installation of the tidal monitoring located in the northeast of the island. Lack of instrument and unallowable condition in the field causing tidal monitoring is only accomplished for 5 days. To extend the range of data, this study applies hydrodynamic modeling using MIKE21. Hence, tidal data can be managed to validate the results of the model.

Tidal data from TMD was carried out at a time interval of 1 hour, from July 1, 2018, to August 31, 2018, using a UTC reference, for adequate comparison with field data. Furthermore, TMD tidal data was used as a comparison against MIKE21 simulation results, with the tidal prediction data from global tide used as a boundary condition of the hydrodynamic model. Groundwater level data were obtained from two measurement locations, namely Wello1 and Well02 with distances of 30 and 250 meters from the coast. Well01 was measured from July 5, 2018, at 10:30 AM till August 17, 2018, at 01:00 PM, while Well02 was measured from July 5, 2018, at 12:10 PM till August 17, 2018, at 10:40 AM, with both data measured during the dry season. These data were used to determine groundwater conditions and their position over several phases of the moon and combined with the hydrodynamic models to obtain a relationship between tides and groundwater.

Groundwater data collected from two monitoring wells, namely Wello1 is about $30 \mathrm{~m}$ and Wello2 is about $250 \mathrm{~m}$ from the shore. Both monitoring wells are located in the northern part of the island. Wello1 has measured on 5 July 2018, at 10.30 West Indonesia Time to 17 August 2018, at 13.00 West Indonesia Time, while Wello2 is measured starting from 5 July 2018, at 12.10 West Indonesia Time to 17 August 2018, at 10.40 West Indonesia Time.
Both wells measured during the dry season at an about one meter in-depth with a 10-minutes interval. This data is applied to determine groundwater conditions and their relative position over several moon-phases and combined with hydrodynamic models to gain a relation between tides and groundwater.

This study did not perform datum references such as Trglavcnik et al. (2018) and Opatz and Dinicola (2018), to reference groundwater levels to sea levels. However, this study implements a relative reference to sea level by measuring groundwater level and sea level at the same time using traditional equipment: water pass tubes. Therefore, the position of the groundwater level can still be referenced to the sea level. Illustration of groundwater level fastening to mean sea level is shown in Figure 2 as follows.

Some of the variables required to bind the groundwater level represent (a) the height of the pipe upon the sea level for a moment; (b) pipe length; (c) shortly of sea-level value; and (d) distance of the sensor from water-table. For a moment of sea-level value represents the condition of sea level when fastening was executed. The sea-level value for a moment was collected from a tidal model to

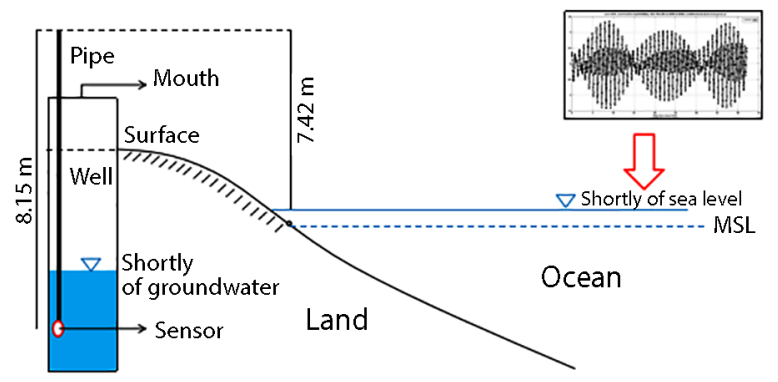

Figure 2. Illustration binding the groundwater to sea level. This process uses tidal model data and groundwater level monitoring data 
fasten groundwater data relative to mean sea level, due to the lack of time-series data. The calculation results produce consequences for errors. The consequence because of using model data not real of field measurements and are unmeasured periodically, so estimation of the error to be high to reference the groundwater level. Hence, the groundwater level position to mean sea level in the study mentioned as the relative groundwater level.

\subsection{Hydrodynamic modeling}

The hydrodynamic model is a shallow water model using hydrodynamic equations: (1) continuity equation and (2) horizontal momentum equation of $\mathrm{x}-\mathrm{y}$ component. Tidal hydrodynamic models were processed using MIKE21. According to Danish Hydraulic Institute [DHI] (2017), the equations are presented using Cartesian coordinates. The local continuity equation is written as Eq. (1) below:

$$
\frac{\partial u}{\partial x}+\frac{\partial v}{\partial y}+\frac{\partial w}{\partial z}=S
$$

And the two horizontal momentum equations for the $\mathrm{x}$ - and $\mathrm{y}$-component is written as Eqs (2) and (3).

$$
\begin{aligned}
& \frac{\partial u}{\partial t}+\frac{\partial u^{2}}{\partial x}+\frac{\partial v u}{\partial y}+\frac{\partial w u}{\partial z}= \\
& f v-g \frac{\partial \eta}{\partial x}-\frac{1}{\rho_{0}} \frac{\partial p_{a}}{\partial x}-\frac{g}{\rho_{0}} \int_{z}^{\eta} \frac{\partial \rho}{\partial x} d z+ \\
& F_{u}+\frac{\partial}{\partial z}\left(v_{t} \frac{\partial u}{\partial z}\right)+u_{s} S ; \\
& \frac{\partial v}{\partial t}+\frac{\partial v^{2}}{\partial y}+\frac{\partial u v}{\partial x}+\frac{\partial w v}{\partial z}= \\
& -f u-g \frac{\partial \eta}{\partial y}-\frac{1}{\rho_{0}} \frac{\partial p_{a}}{\partial y}-\frac{g}{\rho_{0}} \int_{z}^{\eta} \frac{\partial \rho}{\partial y} d z+ \\
& F_{u}+\frac{\partial}{\partial z}\left(v_{t} \frac{\partial v}{\partial z}\right)+v_{s} S,
\end{aligned}
$$

where: $t$ - time; $x, y, z$ - Cartesian co-ordinates; $\eta$ - surface elevation; $d$ - still water depth; $u, v, w$ - velocity components in $x, y, z$ direction; $f$-Coriolis parameter; $g$ - gravitational acceleration; $\rho$ - density of water; $\rho_{0}$ - reference density of water; $p a$ - atmospheric pressure; $v_{t}$ - vertical turbulent or eddy viscosity; $S$ - magnitude of discharge due to point sources; $u_{s}, v_{s}$ - velocity by which the water is discharged into the ambient water.

The steps in the hydrodynamic modeling process include:

1. Mesh generating

The important points in making mesh, particularly

\begin{tabular}{|c|c|c|c|}
\hline \multirow{2}{*}{ No } & \multirow{2}{*}{ Data } & \multicolumn{2}{|r|}{ Source } \\
\hline & & Agency & Sites \\
\hline 1. & $\begin{array}{l}\text { Shore- } \\
\text { line }\end{array}$ & $\begin{array}{l}\text { Geospatial } \\
\text { Information } \\
\text { Agency (BIG) } \\
\end{array}$ & $\begin{array}{l}\text { https://portal.ina-sdi.or.id/ } \\
\text { downloadaoi/ }\end{array}$ \\
\hline 2. & $\begin{array}{l}\text { Bathy- } \\
\text { metry }\end{array}$ & $\begin{array}{l}\text { Geospatial } \\
\text { Information } \\
\text { Agency (BIG) }\end{array}$ & $\begin{array}{l}\text { http://tides.big.go.id/DEMNAS/ } \\
\text { Resolution : } 6 \text { arc-second } \\
( \pm 180 \mathrm{~m})\end{array}$ \\
\hline \multirow{3}{*}{3.} & \multirow{3}{*}{$\begin{array}{l}\text { Boun- } \\
\text { dary } \\
\text { Condi- } \\
\text { tion }\end{array}$} & \multicolumn{2}{|c|}{$\begin{array}{l}\text { Eastern boundary }(\mathrm{BC} 02) \text { : } \\
\text { Start point à }[-7,778 ; 114,413] \\
\text { End point à }[-6,581 ; 114,456]\end{array}$} \\
\hline & & \multicolumn{2}{|c|}{$\begin{array}{l}\text { Northern boundary }(\mathrm{BC} 03) \text { : } \\
\text { Start point à }[-6,581 ; 114,456] \\
\text { End point à }[-6,612 ; 111,713]\end{array}$} \\
\hline & & \multicolumn{2}{|c|}{$\begin{array}{l}\text { Western boundary }(\mathrm{BC} 04) \text { : } \\
\text { Start point à }[-6,612 ; 111,713] \\
\text { End point à }[-6,761 ; 111,702]\end{array}$} \\
\hline
\end{tabular}
grid computing, water depth, and information about boundary conditions (DHI, 2017). The data utilized in creating the mesh are shown in Table 2 as follows.

2. Running hydrodynamic model

Hydrodynamic modeling was generated by using
Table 2. Data utilized for creating the mesh

MIKE21, among the mesh applied is Flow Model Flexible

\begin{tabular}{|c|c|c|}
\hline \multicolumn{3}{|c|}{ Modul: Hydrodynamic Module (HD) } \\
\hline No & Parameter & Penerapan dalam penelitian \\
\hline 1. & $\begin{array}{l}\text { Mesh and } \\
\text { Bathymetri }\end{array}$ & $\begin{array}{l}\text { Generate mesh and bathymetry } \\
\text { interpolation by using the Natural } \\
\text { Neighbor method }\end{array}$ \\
\hline 2. & $\begin{array}{l}\text { Domain } \\
\text { spesification }\end{array}$ & Minimum depth cutoff : -4 \\
\hline 3. & $\begin{array}{l}\text { Boundary } \\
\text { names }\end{array}$ & $\begin{array}{l}\text { Eastern boundary (BC02), Northern } \\
\text { boundary (BC03), dan Western boundary } \\
(\mathrm{BC} 04)\end{array}$ \\
\hline 4. & $\begin{array}{l}\text { Simulation } \\
\text { period }\end{array}$ & $\begin{array}{l}\text { Number of time steps }: 1488 \\
\text { Time step interval : } 3600 \text { detik } \\
\text { Simulation start date }: 1 \text { Juli } 2018 \\
\text { Simulation end date }: 1 \text { September } 2018\end{array}$ \\
\hline 5. & Density & Barotropic \\
\hline 6. & $\begin{array}{l}\text { Eddy } \\
\text { viscosity }\end{array}$ & $\begin{array}{l}\text { Eddy type : Smagorinsky à } 0.28 \text { (konstan) } \\
\text { Minimum eddy viscosity : } 67 \\
\text { Maximum eddy viscosity : } 16666667\end{array}$ \\
\hline 7. & $\begin{array}{l}\text { Bed } \\
\text { resistance }\end{array}$ & Manning number à $32 \mathrm{~m}^{1 / 3}$ \\
\hline 8. & Output & $\begin{array}{l}\text { Point dan area } \\
\text { Output items : surface elevation, } u \\
\text { velocity, v velocity, current speed, current } \\
\text { direction }\end{array}$ \\
\hline
\end{tabular}
Mesh (Flow Model FM), as has been done by Wisha et al. (2018) and Prihantono et al. (2018). Hydrodynamic modeling was provided for two months, starting from 1 July to 31 August 2018. The setup parameters of the hydrodynamic modeling are shown in Table 3 as follows.

Table 3. Setup parameters in hydrodynamic modeling

Validation of the model was generated to determine the accuracy of the model. In other words, to assess an error value of the model. In this study, the validation was performed by comparing the values between the MIKE21 modeling with tidal monitoring. Measuring the accuracy 
by using RMSE (Root Mean Square Error), according to Spaulding and Mendelsohn (1999) and Bayhaqi et al. (2018) are proved by Eq. (4) as follows:

$$
R M S E=\sqrt{\frac{1}{n} \sum_{i=1}^{n}(y-y 1)^{2}},
$$

where: RMSE - Root Mean Square Error; $n$ - total data; $y$ - model data; $y 1$ - field data.

A correlation test was conducted to identify the strength of the linear relationship between predictive and observation data (Barnston, 1992). Correlation data is used to ascertain the relationship between two variables using the correlation coefficient. The correlation coefficient has values extending from -1 (indicates negative correlation) to +1 (denotes positive correlation). The correlation formula is shown in Eq. (5) below.

$$
R=\frac{n \sum x y-(\Sigma x)(\Sigma y)}{\sqrt{\left(n \Sigma x^{2}-(\Sigma x)^{2}\right)\left(n \Sigma y^{2}-(\Sigma y)^{2}\right)}}
$$

where: $R$ - Correlation value; $n$ - Total data; $x$ - Variable $x$ (predictive data); $y$ - Variable $y$ (observational data).

\section{Results and discussion}

\subsection{Model validation and description of tidal conditions in the Madura Strait}

The tidal conditions of the Madura Strait waters are explained through hydrodynamic modeling using MIKE21. The data from the modeling are validated first, producing an RMSE value of $0.202 \mathrm{~m}$ (or $20 \mathrm{~cm}$ ), meaning the model data produce an error of $\pm 0.202 \mathrm{~m}( \pm 20.2 \mathrm{~cm})$ or about $10.30 \%$. The RMSE of the hydrodynamic model must be smaller than 0.4 or $40 \%$ of the standard deviation, referring to Holt et al. (2005); Huang et al. (2010); and Wisha et al. (2018). The standard deviation of the MIKE21 model was $0.58 \mathrm{~m}$, which means the maximum allowable error is $0.23 \mathrm{~m}$, therefore the model results can be used. The correlation coefficient value between field data and MIKE21 model is 0.945 . It indicates a strong relationship between field data and the MIKE21 model. Furthermore, the MIKE21 model can be used for further analysis. Results

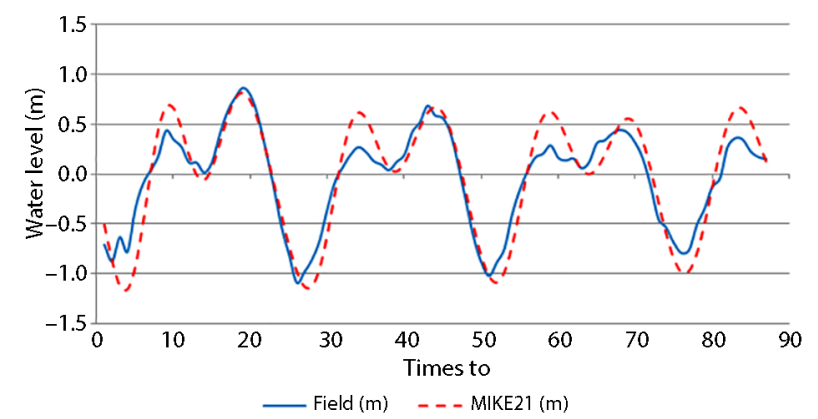

Figure 3. Comparison of the MIKE21 model with field data. The blue line shows field data, while the dashed red line shows the MIKE21 model of validation and correlation test of the MIKE21 model with field data are shown in Figure 3 as follows.

The results of the MIKE21 modeling reveal that sealevel conditions in the Madura Strait waters vary. These variations are recognized by plotting to extract sea level values at several points during the modeling period. Assuming in semi-enclosed bay waters there are possible differences in sea level in particular locations. Therefore, several representative locations were chosen: (1) in the waters around Gili Ketapang Island; and (2) in Madura Strait waters, to suppose the differences in sea level and its implications in the area. Plotting locations and sea-level information of the model are shown in Table 4 and Figure 4 as follows.

Table 4. Sea level variations in several locations based on

\begin{tabular}{|c|c|c|c|c|c|}
\hline \multirow[b]{2}{*}{ No } & \multirow[b]{2}{*}{ Code } & \multirow[b]{2}{*}{ Location } & \multicolumn{2}{|c|}{ Sea level (m) } & \multirow{2}{*}{$\begin{array}{l}{ }^{*} \text { Tidal } \\
\text { Range }(\mathrm{m})\end{array}$} \\
\hline & & & $\begin{array}{l}\text { Maxi- } \\
\text { mum }\end{array}$ & $\begin{array}{l}\text { Mini- } \\
\text { mum }\end{array}$ & \\
\hline 1 & t01 & $\begin{array}{l}\text { Northeastern of } \\
\text { Gili Ketapang } \\
\text { Island }\end{array}$ & 1.320 & -1.535 & 2.855 \\
\hline 2 & $\mathrm{t} 02$ & $\begin{array}{l}\text { Northern of Gili } \\
\text { Ketapang Island }\end{array}$ & 1.324 & -1.540 & 2.864 \\
\hline 3 & t03 & $\begin{array}{l}\text { Western of Gili } \\
\text { Ketapang Island }\end{array}$ & 1.333 & -1.554 & 2.887 \\
\hline 4 & t04 & $\begin{array}{l}\text { Southern of Gili } \\
\text { Ketapang Island }\end{array}$ & 1.319 & -1.536 & 2.855 \\
\hline 5 & t05 & $\begin{array}{l}\text { Eastern of Gili } \\
\text { Ketapang Island }\end{array}$ & 1.311 & -1.526 & 2.837 \\
\hline 6 & t06 & $\begin{array}{l}\text { The mouth } \\
\text { of the semi- } \\
\text { enclosed bay }\end{array}$ & 1.002 & -1.177 & 2.179 \\
\hline 7 & t07 & $\begin{array}{l}\text { The middle part } \\
\text { of the semi- } \\
\text { enclosed bay }\end{array}$ & 1.281 & -1.494 & 2.775 \\
\hline 8 & t08 & $\begin{array}{l}\text { The narrow } \\
\text { mouth of the } \\
\text { Madura Strait } \\
\text { waters }\end{array}$ & 1.309 & -1.172 & 2.481 \\
\hline
\end{tabular}
MIKE21 model

Note: ${ }^{*}$ Tidal Range - value range between maximum and minimum of tides.

The tidal range is determined during the new moon on 13 July 2018.

Points t01 to t05 were around Gili Ketapang Island, with point t01 (northeast of Gili Ketapang Island) as the location of tidal measurements in the field, which was used as validation of MIKE21 simulations. In addition, these points had almost the same sea-level values, with maximum and minimum values of 1.3 and -1.5 meters respectively. The maximum and minimum sea level from the five points was 1.33 meters and -1.55 meters, respectively. It showed that the sea level around Gili Ketapang island had almost the same tendency. This similarity is also seen from the value of tidal range which is the distance between the maximum and minimum sea level. Tidal range 


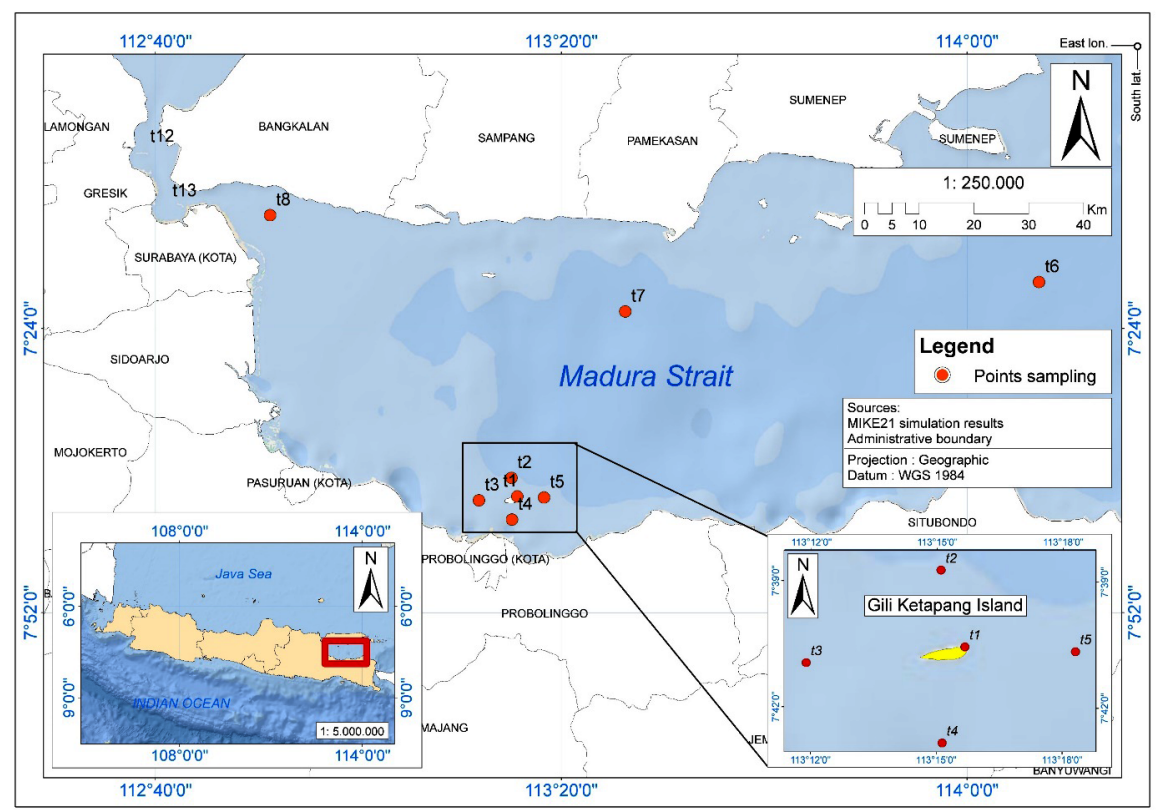

Figure 4. Mapping of the plotting location of sea-level values from the MIKE21 model, where $\mathrm{t} 01$ - t05 (tketapang) points are in the waters nearby Gili Ketapang Island, while t06, t07, and 08 points are in the Madura Strait waters

values at points t01 to t05 were $2.85,2.86,2.88,2.85$, and 2.84 meters, respectively, with an average of 2.86 meters. These values were similar, thereby, indicating that the tidal conditions around Gili Ketapang Island were the same. Based on the calculation, the correlation between $\mathrm{t} 01, \mathrm{t} 02$, $\mathrm{t} 03$, $\mathrm{t} 04$, and $\mathrm{t} 05$ produced a value of 1.0 , meaning that the five points have a very strong correlation.

Regional sea-level characteristics in Madura Strait waters are unique when observed from variations in tidal ranges. This sea-level characterization is classified into two areas, specifically (1) Madura Strait waters, represented by t06, t07, and t08; and (2) the waters nearby Gili Ketapang Island, represented by $\mathrm{t} 01-\mathrm{t} 05$ or tketapang. Based on the tidal range, $\mathrm{t} 06-\mathrm{t} 07$ - $\mathrm{t} 08$ shows fluctuating with consecutive values: $2.18,2.77$, and $2.48 \mathrm{~m}$. This trend can be observed in the spring and neap tide which shows in Figure 5.

Seawater levels around Gili Ketapang Island (t01 - t05) have almost the same value, with a maximum average of

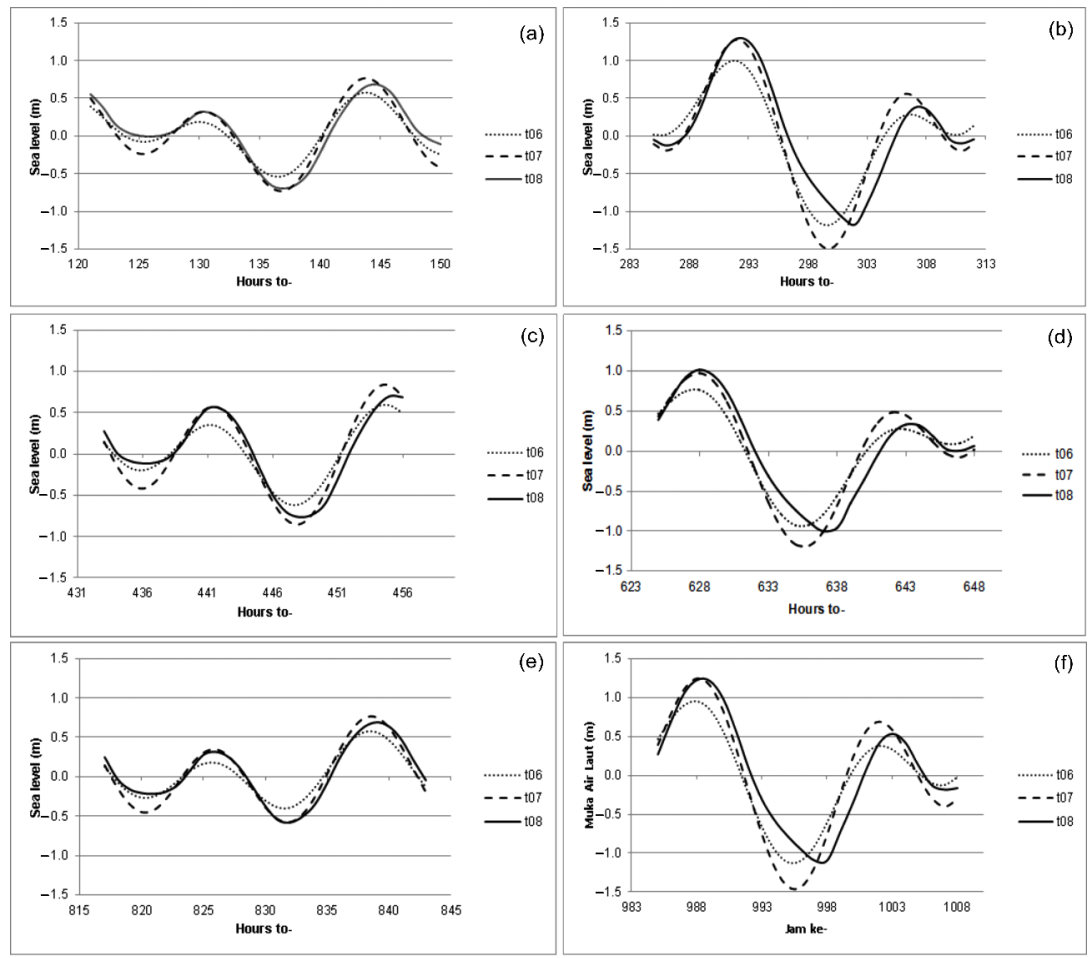

Figure 5. Comparison of sea level t06, t07, and t08 at the phase: new moon, first-quarter, full moon, and third-quarter 
about $1.3 \mathrm{~m}$ and a minimum average of about $-1.5 \mathrm{~m}$. This similarity can also be seen as the tidal value of the t01 - t05 which produces an average of $2.86 \mathrm{~m}$. These conditions indicate the sea level conditions surrounding Gili Ketapang Island are the same. Calculation of the correlation regarding the five points has a correlation value of 1.0 which means the correlation between the five points is extremely strong. Furthermore, there is no significant variation regarding sea-level conditions around the island.

According to Van Rijn (2011), Holleman and Stacey (2014), and Kusmanto et al. (2016) variations of tidal range due to four main things, particularly (a) resonance of standing waves due to the impact of reflected waves especially during a flood; (b) the effect of friction; (c) decreasing the area of the geometry towards the coast or converging geometry; and (d) the effect of inertia. Therefore sea level values of $\mathrm{t} 06, \mathrm{t} 07$, and $\mathrm{t} 08$ are less than $\mathrm{t} 01$ - $\mathrm{t} 05$ because the depth at the $\mathrm{t} 06-\mathrm{t} 08$ point is larger than $\mathrm{t} 01-\mathrm{t} 05$. Whereas $\mathrm{t} 01-\mathrm{t} 05$ or tketapang is due to the impact of shallow waters about the island. Interestingly, tidal range from t06 and t08 smaller than $\mathrm{t} 01$ - t05, but on $\mathrm{t} 07$ has a value approximating t01 - t05.

According to Hadi and Radjawane (2010), resonance in a bay or gulf occurs if the tidal period approximates or has equal value among the natural periods of the bay. Formzahl values in the Madura Strait waters have a value of 0.723 , meaning classified as a mixed tide prevailing semidiurnal with a period of 12.42 hours. Kusmanto et al. (2016) have calculated the natural period of the bay and produce 12.46 hours. This confirms tidal resonance in the Madura Strait waters.

The east-west transect represents by t06 - t08 point designates a mark of elevating at $\mathrm{t} 07$ which means a proof of the tidal amplification process in the Madura Strait waters. According to Kusmanto et al. (2016), this amplification due to the converging geometry toward a semi-closed bay. Illustration of elevating in the Madura Strait waters can be recognized using the MIKE21 model and presented in Figure 6. Whereas, the north-south transect represents by tketapang-t07 shows an insignificant in sea-level differences. It means in 07 and the waters surrounding the island reveal a similar dynamics of the sea level.

Dean and Dalrymple (1991) and Van Rijn (2011) pronounced that tides propagate through the bay waters within bordered by land at the ends will generate the resonance. The resonance means a local tidal amplification in the bay area proximate to the waters. According to Godin (1993), the resonance occurs at a flood event can produce
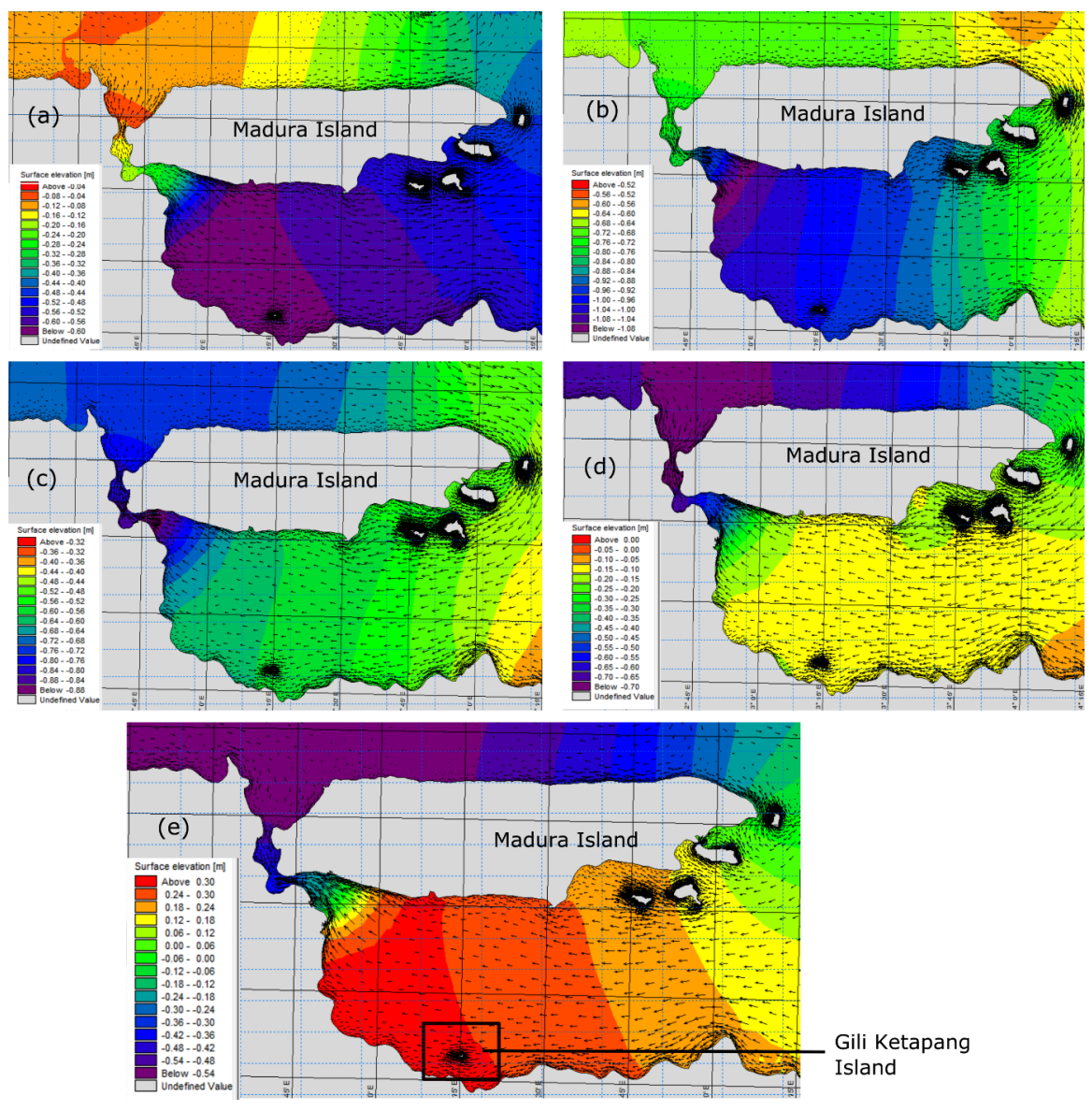

Figure 6. Illustration of tidal elevating in the Madura Strait waters. Figure (a) shows the reflected waves at the ebb event, Figure (b) shows the incoming waves starting to dominate and increasing in Figure (c) and Figure (d). The peak event occurs in Figure

(e), where the incoming waves combine with the reflected waves making a superposition. The illustration is obtained from the hydrodynamic model during the full moon phase on 26 August 2018 at 01.00; 05.00; 06:00; 07.00 and 08.00 WIB 


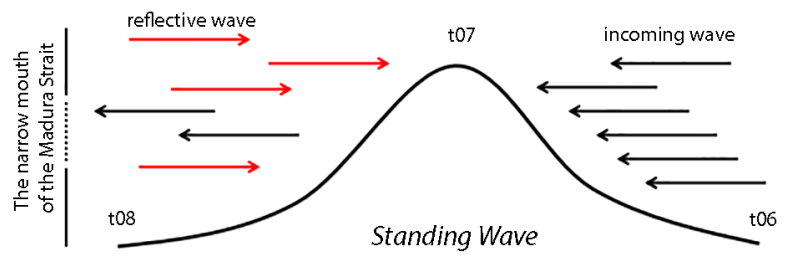

Figure 7. Illustration of wave superposition between incoming waves and reflected waves that produce standing waves

a standing wave. This is reemphasized by Holleman and Stacey (2014), the resonance and convergence of the geometry of the coastline at the edge of the bay waters will generate a rise in sea level. According to this explanation, the 07 point denotes the standing wave occurs.

According to Holleman and Stacey (2014), standing wave resonance is the result of a superposition of incoming waves among reflected waves. In this case, waves originate from the open waters then through t06 point, run and reach the t08 point and hit the shoreline, then reflect and face with the other incoming waves around t07 point. The meeting point generates an increasing water level and result superposition. An illustration of the superposition in the Madura Strait waters shown in Figure 7.

Tidal amplification has various impacts on coastal areas. The southern part of the Madura Strait waters classified as a sub-aerial deposition coast characterized by tidal flat at several locations (Kusmanto et al., 2016). The impacts resulting from tidal amplification include inundation in coastal areas, accumulation, and distribution of sediments that can produce tidal flats, impact in water quality, harbor silting, and those relevant to this study, specifically the impact on groundwater.

\subsection{Groundwater conditions on Gili Ketapang Island}

Groundwater conditions on Gili Ketapang Island in monitoring wells (Well01 and Well02) indicate there are changes in groundwater levels in both well monitoring. During the monitoring, the highest groundwater level in Well01 is $0.025 \mathrm{~m}$ (above the sea level) while the lowest is $-0.365 \mathrm{~m}$ (below the sea level) with an average position is $-0.227 \mathrm{~m}$ relatively. Therefore, during monitoring, the groundwater level position in Wello1 is below sea level relatively. Moreover, during the period of monitoring, the highest in Wello2 is $0.145 \mathrm{~m}$ (above the sea level), while the lowest is $-0.070 \mathrm{~m}$ (below sea level), with an average at the position of $0.020 \mathrm{~m}$ relatively. Figure 8 shows the groundwater fluctuation both the Well01 and Well02.

Based on Figure 8, the groundwater level in the full moon (FM) is lower than in the new moon (NM), although both have similar graph trends. This condition is
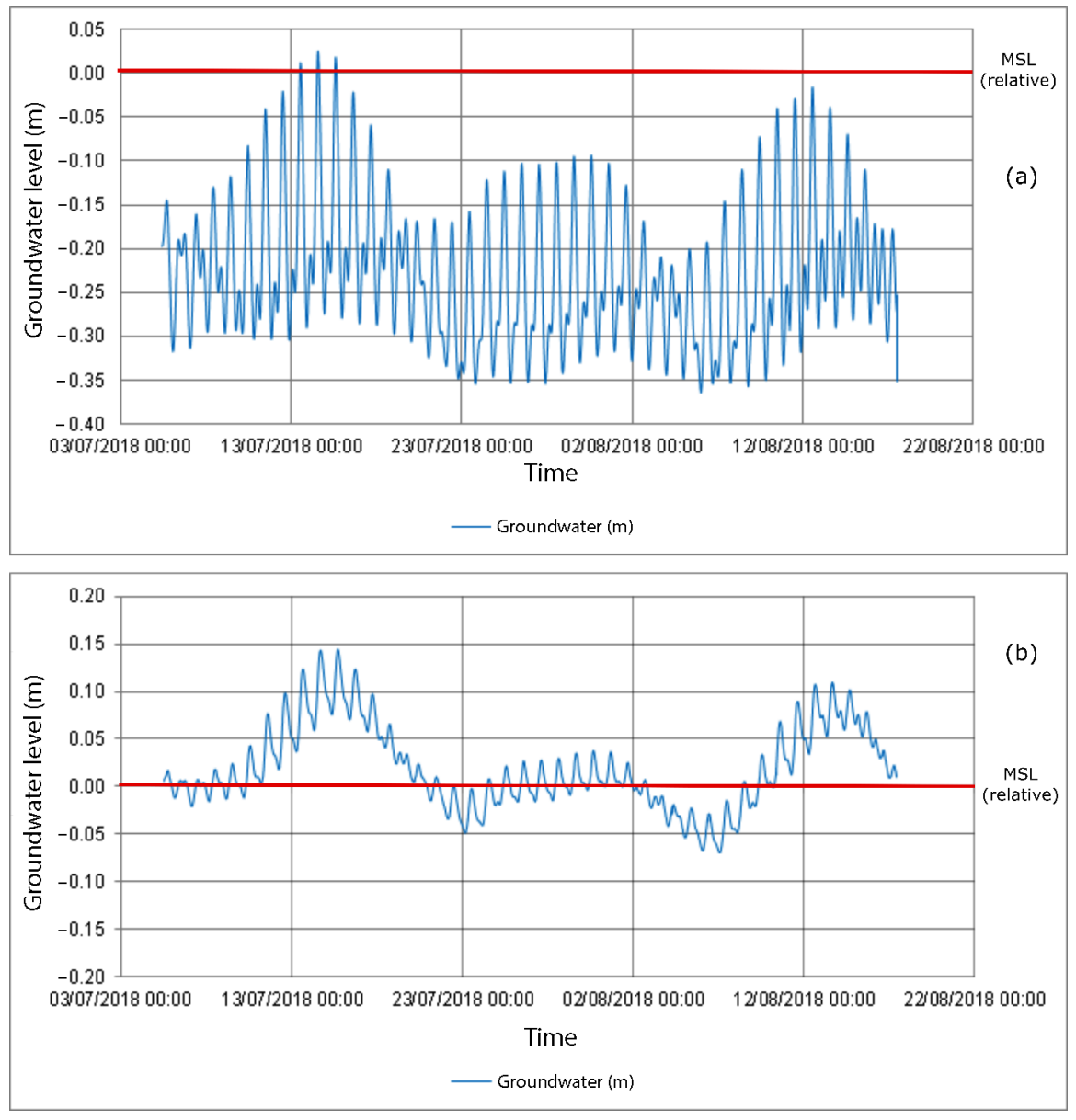

Figure 8. Groundwater level fluctuation on: (a) Well01 and (b) Well02 
Table 5. The groundwater level for each moon phase

\begin{tabular}{|l|l|l|l|l|l|}
\hline & \multicolumn{1}{|c|}{ New Moon } & \multicolumn{1}{c|}{ First Quarter } & \multicolumn{1}{c|}{ Full Moon } & \multicolumn{1}{c|}{ Third Quarter } \\
\hline Max elevation & $0.025 \mathrm{~m}$ & $-0.129 \mathrm{~m}$ & $-0.109 \mathrm{~m}$ & $-0.079 \mathrm{~m}$ \\
\hline Date & 14 July 2018 & 24 July 2018 & 28 July 2018 & 09 August 2018 \\
\hline Time & $15: 40 \mathrm{WIB}$ & $12: 40 \mathrm{WIB}$ & $14: 40 \mathrm{WIB}$ & $12: 30 \mathrm{WIB}$ \\
\hline Min elevation & $-0.280 \mathrm{~m}$ & $-0.354 \mathrm{~m}$ & $-0.343 \mathrm{~m}$ & $-0.365 \mathrm{~m}$ \\
\hline Date & 15 July 2018 & 25 July 2018 & 28 July 2018 & 06 August 2018 \\
\hline Time & $00: 10 \mathrm{WIB}$ & $21: 50 \mathrm{WIB}$ & $23: 00 \mathrm{WIB}$ & $01: 50$ WIB \\
\hline Max elevation & $0.145 \mathrm{~m}$ & $0.022 \mathrm{~m}$ & $0.038 \mathrm{~m}$ & $0.034 \mathrm{~m}$ \\
\hline Date & 15 July 2018 & 25 July 2018 & 30 July 2018 & 09 August 2018 \\
\hline Time & $17: 02 \mathrm{WIB}$ & $14: 40$ WIB & $16: 50 \mathrm{WIB}$ & $15: 20$ WIB \\
\hline Min elevation & $0.059 \mathrm{~m}$ & $-0.049 \mathrm{~m}$ & $-0.015 \mathrm{~m}$ & $-0.070 \mathrm{~m}$ \\
\hline Date & 14 July 2018 & 25 July 2018 & 30 July 2018 & 07 August 2018 \\
\hline Time & $08: 00 \mathrm{WIB}$ & $05: 00$ WIB & $07: 40$ WIB & $03: 00$ WIB \\
\hline
\end{tabular}

related to the distance of the Moon from the Earth when the new moon (NM) phase on 13 July 2018 is the closest distance (perigee) which is $357,434 \mathrm{~km}$, while the full moon (FM) phase 28 July 2018) is the furthest distance (apogee) which is 405,953 km (Badan Meteorologi, Klimatologi, dan Geofisika [BMKG], 2018). Tides influenced by the gravitational forces of astronomical objects such as the sun, earth, the moon. Hence, the farther the distance provides a weak gravitational force dan less on the tidal amplitude.

Purnama (2010) stated groundwater level changes affected by several things i.e. flow variation, weather variations, tides, earthquakes, loading from the outside, and subsidence. Variations in groundwater level also indicate differences inflow-outflow in monitoring wells. In Figure 8, the graph of Well01 is tighter than Well02. It means groundwater in Wello1 provides more fluctuating and more rapid variations than in Well02. The most significant fluctuation in Well01 and Well02 is during the new moon (NM) phase. Each of the phases the groundwater level also has a variation value shown in Table 5. The graph pattern of both wells shows an asymmetric as declared by Horn (2002), Wu and Zhuang (2010), and Singaraja et al. (2018). The difference in groundwater position between Well01 and Wello2 reveals the impact of variation distance from the coast. This study did not measure the other factors like evapotranspiration, whereas monitoring was conducted during the dry season which has quite high evapotranspiration. Therefore, collected data have potentially biased because it has been unfiltered with other measurable factors.

\subsection{Effect of tides on groundwater}

Tides and groundwater level fluctuations in Figure 9 and Figure 10 show there are similar graph patterns. The graph pattern reveals the tides on the new moon phase (NM) are higher than during the full moon (FM). This trend is followed by groundwater conditions, particularly when the new moon (NM) groundwater levels in Wello1 and
Well02 be higher than during the full moon (FM). This means the influence of tides on groundwater. The tidal and groundwater graphs show the tidal and groundwater graphs on Well01 have a related, different from Well02. It means the effect of tides on Well01 is higher than Well02.

The effect of tides on groundwater inland affected by the distance from the coast, increasing the distance

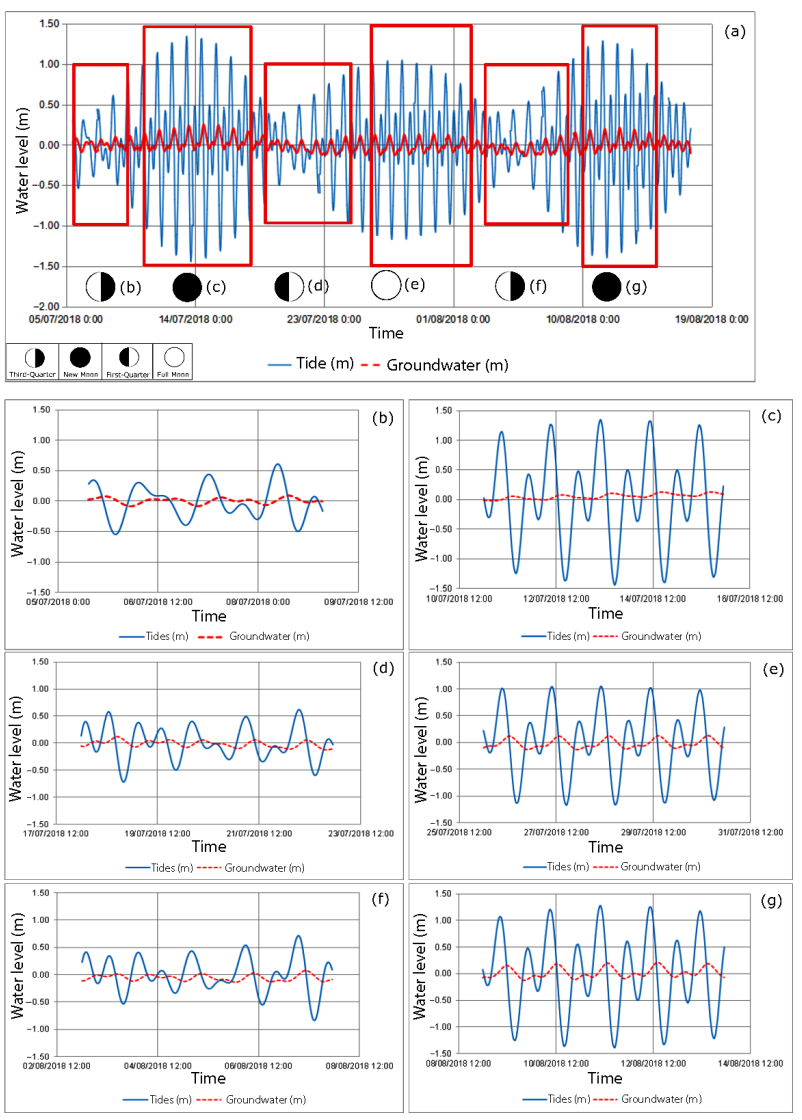

Figure 9. The sea-level fluctuations with groundwater levels in Well01. Description of the moon phase: (b) third-quarter;

(c) new month; (d) first-quarter; (e) full moon; (f) third-quarter; (g) new moon 

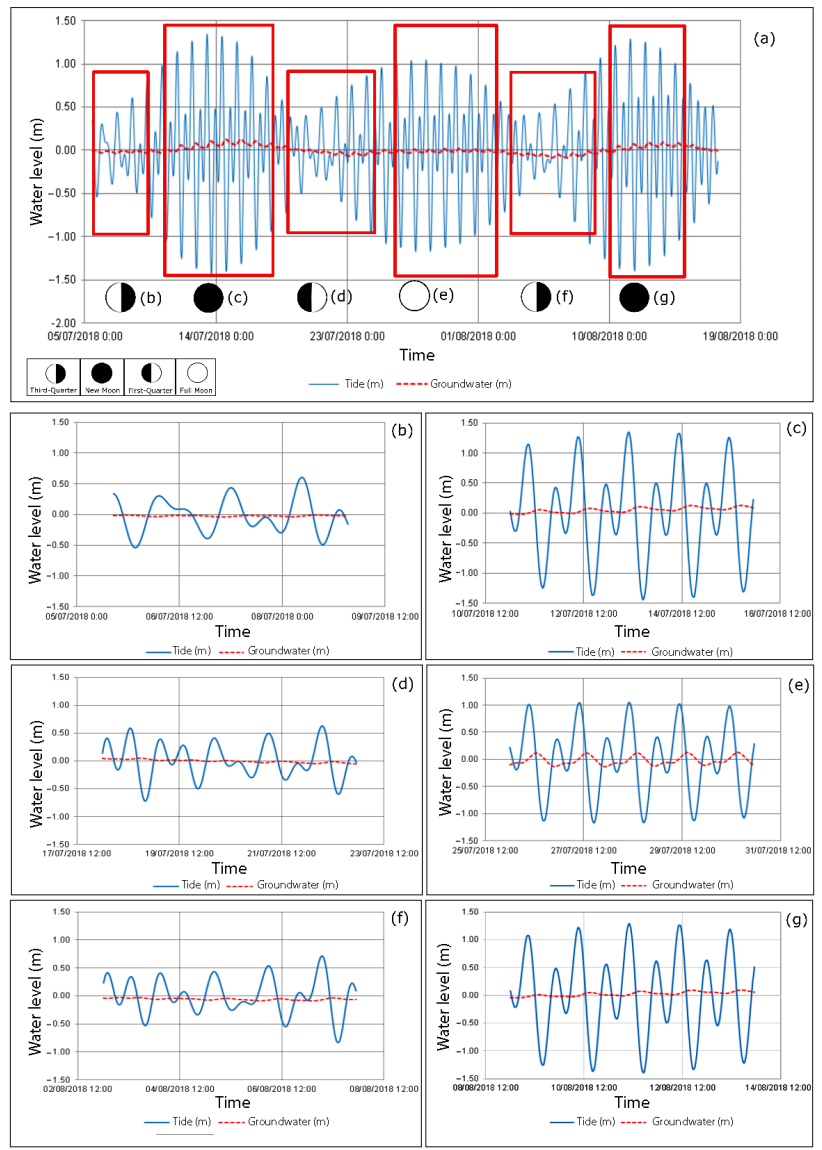

Figure 10. The sea-level fluctuations with groundwater levels in Well02. Description of the moon phase: (b) third-quarter;

(c) new month; (d) first-quarter; (e) full moon;

(f) third-quarter; (g) new moon

towards the land will decreasing the effect. Previous research also found the impact of tides on groundwater level fluctuations in coastal areas is characterized by a decrease in amplitude with increasing distance from the coast (Nielsen, 1990; Xun et al., 2006, 2015; Liu et al., 2012; Levanon et al., 2016; Trglavcnik et al., 2018). This is reported from the graph both Well01 and Wello2 which decreasing in amplitude. Farther distance from the coast provides more distantly because groundwater changes are slowly and require a longer duration. Previous research with analytical methods, numerical models, and field monitoring also found groundwater amplitude decreased exponentially with distance, but this has been unfound in this study because groundwater monitoring data are only two points.

The amplitude decreases due to the constituent material in coastal or physical areas (Hegge \& Masselink, 1991) especially the beach is often defined as a low-pass filter in beach groundwater science (Horn, 2002). It means only the low-frequency oscillations are transmitted through a beach matrix, whereas high-frequency oscillations are limited to the intertidal beach face slope zone. This is confirmed in Werner and Lockington (2003) groundwater level fluctuations in unconfined aquifers that are associated with low-frequency tidal oscillations.

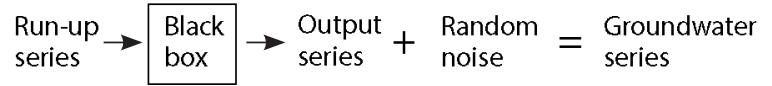

Figure 11. Conceptual the coherence and the gain function to examine the relationship between run-up and groundwater (illustration from Hegge \& Masselink, 1991)

The relation between tides and groundwater explained in the conceptual framework of Hegge and Masselink (1991) presented in Figure 11. The black box represents a function of the beach action to reduce the amplitude and frequency of the input of swash energy. Beach slope also is confirmed to have an impact on changes in amplitude. Liu et al. (2012) found a sloping beach has a more important influence on the amplitude of the water fluctuation than a vertical beach. Jeng et al. (2005) also found that water fluctuations vary inversely with the beach slope, although they have not derived a particular form about the relationship between the amplitude and beach angle. Furthermore, the attenuation is caused by water saturation and effect on the land (Levanon et al., 2016) especially in the capillary zone (a part in the unsaturated zone).

Horn (2002), Xun et al. (2006, 2015), Levanon et al. (2016), Trglavcnik et al. (2018) and many researchers on similar topics mentioned besides decreasing amplitude, increasing distance to the land generates time lag to increase. Increasing the groundwater level can occur at a different time with the rising of tidal. In general, the tidal rise first, then the groundwater follows, this process will produce a time lag. The time lag occurs when there is a difference in time both sea-level and groundwater level rise. This study uses a time difference between a peak in the tide and the corresponding peak in the hydraulic head. The calculation of time lag shown in Table 6 and Table 7.

Table 6. Calculation of the time lag in Wello1

\begin{tabular}{|c|l|l|c|}
\hline No & Moon Phase & \multicolumn{1}{|c|}{ Date } & Time lag (hours) \\
\hline 1 & \multirow{2}{*}{ New moon } & 11-15 July 2018 & 3.6 \\
\cline { 3 - 4 } 2 & & 9-11 August 2018 & 3.6 \\
\hline 3 & First Quarter & 18-22 July 2018 & 4.4 \\
\hline 4 & Full moon & 26-30 July 2018 & 3.6 \\
\hline 5 & \multirow{2}{*}{ Third Quarter } & 5-8 July 2018 & 4.5 \\
\cline { 3 - 4 } & & 3-7 August 2018 & 4.4 \\
\hline \multicolumn{3}{|c|}{ Average } & 4.02 \\
\hline
\end{tabular}

Table 7. Calculation of the time lag in Well02

\begin{tabular}{|c|l|l|c|}
\hline No & Moon Phase & \multicolumn{1}{c|}{ Date } & Time lag (hours) \\
\hline 1 & \multirow{2}{*}{ New moon } & 11-15 July 2018 & 5.8 \\
\cline { 3 - 4 } 2 & & 9-11 August 2018 & 5.8 \\
\hline 3 & First Quarter & 18-22 July 2018 & 5.6 \\
\hline 4 & Full moon & 26-30 July 2018 & 5.6 \\
\hline 5 & \multirow{2}{*}{ This Quarter } & 5-8 July 2018 & 5.7 \\
\cline { 3 - 4 } 6 & 3-7 August 2018 & 5.6 \\
\hline \multicolumn{3}{|c|}{ Average } & 5.68 \\
\hline
\end{tabular}


Based on Tables 6 and 7, the time lag between Well01 and 02 is varied. Wello1 and 02 have the lowest time lag value of 3.6 and 5.6 hours occurred in the new and full moon phases, while the time lag during the neap tide (first and third quarters) about $4.4-4.5$ hours. The average time lag on Well01 and Well02 is 4.02 and 5.68 hours, respectively. The calculation shows increasing the distance from the coast includes a consequent more prolonged duration in response to tidal. These results are following Erskine (1991), Kim et al. (2006), Xun et al. (2006), Levanon et al. (2016, 2017).

The effect of tides on groundwater is one of the hydrodynamic processes in the coastal areas. For a small island, the hydrodynamic process produces an extensive impact, especially groundwater dynamics on a small island. The technical practice of this research is related to how to manage and protect the freshwater resources on a small island. Conservation of water must become a household responsibility. White et al. (2007) state that behavioral change in all levels is important to conserving and protecting water in small islands. Although this requires a recognition of the unique cultural, social, economic, and geographical in contexts of small islands and might be long-term commitments.

The implications of this study provide input and enrich methods to recognize the relationship between tides and groundwater. Although this research nonetheless has many shortcomings and needs to be improved for the following research, for example, material objects such as groundwater quality and aquifer properties need to be studied more thoroughly, especially on the island of Gili Ketapang, as well as sufficiently advanced combination methods can be applied. Regionally, the implications of this research include the framework of managing and protecting water resources in small islands and coastal areas. The dynamic of hydro-oceanography studies on small islands possess the potential to improve in Indonesia because the topic is relevant to the national project specifically national research master plan or RIRN, especially on the topic developing in technologies and managing small island and coastal areas.

\section{Conclusions}

In conclusion, the effects of tides can be identified by using a combination of field monitoring and hydrodynamic modeling. The condition of the Madura Strait waters exposes a standing wave phenomenon as a result of tidal resonance. This phenomenon has an influence on groundwater on Gili Ketapang Island because the sea level around the island is identical to the sea level of the Madura Strait which affected by resonance. Groundwater conditions on Gili Ketapang Island are described as follows: (1) fluctuations in each phase of the month with the highest values during a spring tide (2) groundwater graph is more tenuous as the distance from the coast increases, and (3) the amplitude decreases as the distance from the coast increases. The effect of tides on groundwater can be proven by the general characteristics of the decrease in amplitude and increasing of time lags as the distance from the coast increases. This process is determined by beach material and beach slope.

\section{Acknowledgements}

The authors are grateful to the Marine Research Center of the Agency of Research and Human Resources for Marine and Fisheries (BRSDM-KP), the DDRG-LIPI research team which consists of the Ministry of Maritime Affairs and Fisheries (KKP), the Indonesian Institute of Sciences ( LIPI), and Jenderal Soedirman University (Unsoed) for their assistance in carrying out this study. All data were provided by the Coremap-DDRG-LIPI 2018 Project.

\section{References}

Abarca, E., Karam, H., Hemond, H. F., \& Harvey, C. F. (2013). Transient groundwater dynamics in a coastal aquifer: The effects of tides, the lunar cycle, and the beach profile. Water Resources Research, 49(5), 2473-2488.

https://doi.org/10.1002/wrcr.20075

Abdullah, M. H., Mokhtar, M. B., Tahir, S. H., \& Awaludin, A. B. (1997). Do tides affect water quality in the upper phreatic zone of a small oceanic island, Sipadan Island, Malaysia? Environmental Geology, 29, 112-117. https://doi.org/10.1007/s002540050109

Ataie-Ashtiani, B., Volker, R. E., \& Lockington, D. A. (2001). Tidal effects on groundwater dynamics in unconfined aquifers. Hydrological Processes, 15(4), 655-669. https://doi.org/10.1002/hyp.183

Badan Meteorologi, Klimatologi, dan Geofisika. (2018). FaseFase Bulan dan Jarak Bumi-Bulan pada Tahun 2018. Jakarta. https://www.bmkg.go.id/?lang=ID

Banerjee, P., Singh, V. S., Singh, A., Prasad, R. K., \& Rangarajan, R. (2012). Hydrochemical analysis to evaluate the seawater ingress in a small coral island of India. Environmental Monitoring and Assessment, 184, 3929-3942.

https://doi.org/10.1007/s10661-011-2234-0

Barnston, A. G. (1992). Correspondence among the correlation, RMSE, and Heidke Foresast verification measures; Refinement of the Heidke Score. Weather and Forecasting, 7(4), 699-709. https://doi.org/10.1175/1520-0434(1992)007<0699:CATCRA $>2.0$.CO;2

Bayhaqi, A., Wisha, U. J., \& Surinati, D. (2018). Modeling tidal current of Banten Bay during transitional monsoons 20152016. Jurnal Segara, 14(2), 95-105. https://doi.org/10.15578/segara.v14i2.6452

Cui, X., Fang, G., \& Wu, D. (2019). Tidal resonance in the Gulf of Thailand. Ocean Science. 15(2), 321-331. https://doi.org/10.5194/os-15-321-2019

Dean, R. G., \& Dalrymple, R. A. (1991). Anvanced series on ocean engineering: Vol. 2. Water wave mechanics for engineers and scientists. World Scientific Publisher. https://doi.org/10.1142/1232

Danish Hydraulic Institute. (2017). MIKE 21 flow model FM: Hydrodynamic module. User guide. https://manuals.mikepoweredbydhi.help/2017/Coast_and_Sea/MIKE_FM_HD_2D.pdf

Dong, L., Shimada, J., Kagabu, M., \& Yang, H. (2015). Barometric and tidal-induced aquifer water level fluctuation near the Ariake Sea. Environmental Monitoring and Assessment, 187(1), 4187-4203. https://doi.org/10.1007/s10661-014-4187-6 
Erskine, A. D. (1991). The effect of tidal fluctuation on a coastal aquifer in UK. Groundwater, 29(4), 556-562.

https://doi.org/10.1111/j.1745-6584.1991.tb00547.x

Falkland, A. C. (1993). Hydrology and water management on small tropical islands. In J. S. Gladwell, Hydrology of Warm Humid Regions (pp. 263-303). IAHS Press.

Falkland, A. C., Custodio, E., Diaz Arenas, A., \& Simler, L. (1991). Hydrology and water resources of small islands: A practical guide. UNESCO Publisher.

Fetter, Jr. C. W. (1972). Position of the saline water interface beneath oceanic islands. Water Resources Research, 8(5), 13071315. https://doi.org/10.1029/WR008i005p01307

Geospatial Information Agency. (2019, 25 June). Raster of bathymetry: BATNAS_110E-115E_10S-05S_MSL_v1.1. http://tides.big.go.id/DEMNAS/

Geospatial Information Agency. (2019, 25 June). Shapefile of shoreline data of East Java. Indonesia-Geospatial Portal. https://portal.ina-sdi.or.id/downloadaoi/

Godin, G. (1993). On tidal resonance. Continental Shelf Research, 13(1), 89-107.

https://doi.org/10.1016/0278-4343(93)90037-X

Hadi, S., \& Radjawane, I.M. (2010). Arus Laut. Institut Teknologi Bandung.

Hegge, B. J., \& Masselink, G. (1991). Groundwater-table responses to wave run-up: An experimental study from Western Australia. Journal of Coastal Research, 7(3), 623-634.

Heiss, J. W., \& Michael, H. A. (2014). Saltwater-freshwater mixing dynamics in a sandy beach aquifer over tidal, spring-neap, and seasonal cycles. Water Resources Research, 50(8), 67476766. https://doi.org/10.1002/2014WR015574

Hidayati, N., Purnawali, H. S., \& Kusumawati, D. W. (2016). Prediksi perubahan garis pantai Pulau Gili Ketapang, Probolinggo dengan menggunakan one-line model [Coference presentation]. Seminar Nasional Perikanan dan Kelautan VI, Fakultas Perikanan dan Ilmu Kelautan, Universitas Brawijaya, Malang.

Hill, D. F. (2016). Spatial and temporal variability in tidal range: Evidence, causes, and effects. Current Climate Change Reports, 2, 232-241. https://doi.org/10.1007/s40641-016-0044-8

Holleman, R. C., \& Stacey, M. T. (2014). Coupling of sea level rise, tidal amplification, and inundation. Journal of Physical Oceanography, 44(5), 1439-1455.

https://doi.org/10.1175/JPO-D-13-0214.1

Holt, J. T., Allen, J. I., Proctor, R., \& Gilbert, F. (2005). Error quantification of a high-resolution coupled hydrodynamicecosystem coastal-ocean model: Part 1 model overview and assessment of the hydrodynamics. Journal of Marine Systems, 57(1-2), 167-188.

https://doi.org/10.1016/j.jmarsys.2005.04.008

Horn, D. P. (2002). Beach groundwater dynamics. Geomorpho$\log y, 48(1-3), 121-146$.

https://doi.org/10.1016/S0169-555X(02)00178-2

Hsieh, P., Hsu, H., Liao, C. B., \& Chiueh, P. (2015). Groundwater response to tidal fluctuation and rainfall in a coastal aquifer. Journal of Hydrology, 521, 132-140.

https://doi.org/10.1016/j.jhydrol.2014.11.069

Huang, A., Rao, Y. R., \& Lu, Y. (2010). Evaluation of a 3-D hydrodynamic model and atmospheric forecast forcing using observations in Lake Ontario. Journal of Geophysical Research, 115(2), C02004. https://doi.org/10.1029/2009JC005601

Huang, F., Chuang, M., Wang, G. S., \& Yeh, H. (2015). Tideinduced groundwater level fluctuation in a U-shaped coastal aquifer. Journal of Hydrology, 530, 291-305. https://doi.org/10.1016/j.jhydrol.2015.09.032
Husrin, S. (2018). Kajian Daya Dukung Sumberdaya Airtanah di Pulau Kecil yang Berpenduduk Padat (Studi Kasus: Pulau Gili Ketapang, Probolinggo, Jawa Timur) [Conference presentation]. Kuliah Umum Analisis Kerentanan Pesisir dari Sisi Teknik Pantai. Fakultas Geografi Universitas Gadjah Mada.

Jasonsmith, J. F., Macdonald, B. C. T., \& White, I. (2017). Earthtide-induced fluctuations in the salinity of an inland river, New South Wales, Australia: A short-term study. Environmental Monitoring and Assessment, 189, 188.

https://doi.org/10.1007/s10661-017-5880-z

Jeng, D. S., Li, L., \& Barry, D. A. (2002). Analytical solution for tidal propagation in a coupled semi-confined/phreatic coastal aquifer. Advances in Water Resources, 25(5), 577-584.

https://doi.org/10.1016/S0309-1708(02)00016-7

Jeng, D. S., Mao, X., Enot, P., Barry, D. A., Li, L., \& Binlet, A. (2005). Spring-neap tide-induced beach water table fluctuations and its influence on the behaviour of a coastal aquifer adjacent to a low-relief estuary (Research Report). Department of Civil Engineering, University of Sydney.

Kim, J., Lee, J., Cheong, T., Kim, R., Koh, D., Ryu, J., \& Chang, H. (2005). Use of time series analysis for the identification of tidal effect on groundwater in the coastal area of Kimje, Korea. Journal of Hydrology, 300(1-4), 188-198. https://doi.org/10.1016/j.jhydrol.2004.06.004

Kim, K., Seong, H., Kim, T., Park, K., Woo, N., Park, Y., Koh, G., \& Park, W. (2006). Tidal effects on variations of fresh - saltwater interface and groundwater flow in a multilayered coastal aquifer on a volcanic island (Jeju Island, Korea). Journal of Hydrology, 330(1-4), 525-542. https://doi.org/10.1016/j.jhydrol.2006.04.022

Kusmanto, E., Hasanudin, M., \& Setyawan, W. B. (2016). Amplifikasi Pasang Surut dan Dampaknya terhadap Perairan Pesisir Probolinggo. Oseanologi dan Limnologi di Indonesia, 1(3), 69-80.

Levanon, E., Shalev, E., Yechieli, Y., \& Gvirtzman, H. (2016). Fluctuations of fresh-saline water interface and of water table induced by sea tides in unconfined aquifers. Advances in Water Resources, 96, 34-42.

https://doi.org/10.1016/j.advwatres.2016.06.013

Levanon, E., Yechielli, Y., Gvirtzman, H., \& Shalev, E. (2017). Tide-induced fluctuations of salinity and groundwater level in unconfined aquifers - Field measurements and numerical model. Journal of Hydrology, 551, 665-675. https://doi.org/10.1016/j.jhydrol.2016.12.045

Liu, Y., Shang, S., \& Mao, X. (2012). Tidal effects on groundwater dynamics in coastal aqui- fer under different beach slopes. Journal of Hydrodynamics, 24(1), 97-106. https://doi.org/10.1016/S1001-6058(11)60223-0

Mao, X., Enot, P., Barry, D. A., Li, L., Binley, A., \& Jeng, D.-S. (2006). Tidal influence on behaviour of a coastal aquifer adjacent to a low-relief estuary. Journal of Hydrology, 327(1-2), 110-127. https://doi.org/10.1016/j.jhydrol.2005.11.030

Narulita, I., Santoso, H., Hantoro, W. S., \& Djuwansah, M. R. (2005). Pengaruh pasang surut laut terhadap posisi kualitas air tanah di Pulau Pari, Kepulauan Seribu, DKI Jakarta. In P. E. Hehanussa, \& H. Bakti, Sumberdaya Air di Pulau Kecil. Indonesian Institute of Sciences.

Nielsen, P. (1990). Tidal dynamics of the water table in beaches. Water Resources Research, 26(9), 2127-2134. https://doi.org/10.1029/WR026i009p02127

Opatz, C. C., \& Dinicola, R. S. (2018). Analysis of groundwater response to tidal fluctuations, Operable Unit 2, Area 8, Naval Base Kitsap, Keyport, Washington (Open-File Report 20181082). U.S. Geological Survey. https://doi.org/10.3133/ofr20181082 
Pauw, P. S., Essink, G. H. P. O., Leijnse, A., Vandenbohede, A., Groen, J., \& van der Zee, S. E. A. T. M. (2014). Regional scale impact of tidal forcing on groundwater flow in unconfined coastal aquifers. Journal of Hydrology, 517, 269-283. https://doi.org/10.1016/j.jhydrol.2014.05.042

Prihantono, J., Fajrianto, I. A., \& Kurniadi, Y. N. (2018). Pemodelan hidrodinamika dan transpor sedimen di perairan pesisir sekitar Tanjung Pontang, Kabupaten Serang - Banten. Jurnal Kelautan Nasional, 13(2), 75-88. https://doi.org/10.15578/jkn.v1i2.6614

Purnama, S. (2010). Hidrologi Airtanah. Kanisius.

Robinson, C., Li, L., \& Prommer, H. (2007). Tide-induced recirculation across the aquifer-ocean interface. Water Resources Research, 43, W07428. https://doi.org/10.1029/2006WR005679

Singaraja, C., Chidambaram, S., \& Jacob, N. (2018). A study on the influence of tides on the water table conditions of the shallow coastal aquifers. Applied Water Science, 8, 11. https://doi.org/10.1007/s13201-018-0654-5

Spaulding, M. L., \& Mendelsohn, D. L. (1999). WQMAP: An integrated three-dimensional hydrodynamic and water quality model system for estuarine and coastal applications. Marine Technology Society Journal, 33(3), 38-54. https://doi.org/10.4031/MTSJ.33.3.6

Sutherland, G., Garrett, C., \& Foreman, M. (2005). Tidal resonance in Juan de Fuca strait and the strait of Georgia. Journal of Physical Oceanography, 35(7), 1279-1286. https://doi.org/10.1175/JPO2738.1

Todd, D. K. (1980). Groundwater hydrology (2 ${ }^{\text {nd }}$ ed.). John Wiley \& Sons.

Trglavcnik, V., Morrow, D., Weber, K. P., Li, L., \& Robinson, C. E. (2018). Analysis of tide and offshore storm-induced water table fluctuations for structural characterization of a coastal island aquifer. Water Resources Research, 54(4), 2749-2767. https://doi.org/10.1002/2017WR020975

Urish, D. W., \& Mckenna, T. E. (2004). Tidal effects on ground water discharge through a sandy marine beach. Groundwater, 42(7), 971-982. https://doi.org/10.1111/j.1745-6584.2004.tb02636.x

Van Rijn, L. C. (2011). Analytical and numerical analysis of tides and salinities in estuaries; Part I: Tidal wave propagation in convergent estuaries. Ocean Dynamics, 61, 1719-1741. https://doi.org/10.1007/s10236-011-0453-0
Vandenbohede, A., \& Lebbe, L. (2007). Effects of tides on a sloping shore: Groundwater dynamics and propagation of the tidal wave. Hydrogeology Journal, 15, 645-658.

https://doi.org/10.1007/s10040-006-0128-y

Webb, D. J. (2014). On the tides and resonances of Hudson Bay and Hudson Strait. Ocean Science, 10, 411-426. https://doi.org/10.5194/os-10-411-2014

Werner, A. D., \& Lockington, D. A. (2003). Influence of hysteresis on tidal capillary fringe dynamics in a well-sorted sand. Advances in Water Resources, 26(11), 1199-1204. https://doi.org/10.1016/S0309-1708(03)00107-6

White, I., Falkland, T., Perez, P., Dray, A., Metutera, T., Metai, E., \& Overmars, M. (2007). Challenges in freshwater management in low coral atolls. Journal of Cleaner Production, 15(16), 1522-1528. https://doi.org/10.1016/j.jclepro.2006.07.051

Wisha, U. J., Tanto, T. A., Pranowo, W. S., \& Husrin, S. (2018). Current movement in Benoa Bay water, Bali, Indonesia: Pattern of tidal current changes simulated for the condition before, during, and after reclamation. Regional Studies in Marine Science, 18, 177-187. https://doi.org/10.1016/j.rsma.2017.10.006

Wu, L., \& Zhuang, S. (2010). Experimental investigation of effect of tide on coastal groundwater table. Journal of Hydrodynamics, 22(1), 66-72. https://doi.org/10.1016/S1001-6058(09)60029-9

Xun, Z., Chao, S., Ting, L., \& Ruige, C. (2015). Estimation of aquifer parameters using tide-induced groundwater level measurements in a coastal confined aquifer. Environment Earth Science, 73, 2197-2204. https://doi.org/10.1007/s12665-014-3570-5

Xun, Z., Chuanxia, R., Yanyan, Y., Bin, F., \& Yecheng, O. (2006). Tidal effects of groundwater levels in the coastal aquifers near Beihai, China. Environmental Geology, 51, 517-525. https://doi.org/10.1007/s00254-006-0348-4

Zhang, Y., Li, L., Erler, D. V., Santos, I., \& Lockington, D. (2017). Effects of beach slope breaks on nearshore groundwater dynamics. Hydrological Processes, 31(14), 2530-2540. https://doi.org/10.1002/hyp.11196 